\title{
Maya subsistence hunters in Quintana Roo, Mexico
}

\author{
Jeffrey P. Jorgenson
}

Wild animals have played an important role in the lives of Maya Indians but recent evidence from a small Maya community in south-eastern Mexico suggests that their importance as a source of food may be diminishing. The persistence of subsistence hunting despite low kill rates suggests that hunting is still culturally important to the Maya community as a whole. By combining subsistence hunting with other subsistence and commercial activities, such as gardening and the extraction of chicle latex from sapodilla trees Manilkara zapota, contemporary Maya hunters are preserving a culturally important activity while simultaneously adapting to internal and external pressures to modernize their society.

Wildlife is important to colonists and indigenous people in Latin America (Redford and Robinson, 1987; Robinson and Redford, 1991). Three specific roles have been identified for wild animals (Vickers, 1991). First, wild animals are important in human diets (Bodmer et al., 1988; Stearman, 1989; Dufour, 1990; Ayres et al., 1991). Second, animals are important for cultural reasons. They are kept as pets, their bones and teeth are used to make tools, and various parts are used for ornaments (Yost and Kelley, 1983; Thomsen and Braütigam, 1991). Third, wild animals are part of the art and mythology of many groups (McDonald, 1977; Ross, 1978; Balée, 1985).

Contemporary and historical evidence show that wild animals are important to Maya Indians in Central America. Archaeological studies in Mexico and Guatemala have revealed that Maya Indians in pre-Columbian times consumed several species of insects, amphibians, reptiles, birds and mammals (Pohl, 1976; Hamblin, 1984). They also kept wild animals such as white-tailed deer Odocoileus virginianus and collared peccaries Tayassu tajacu as pets, and used wild animal parts to make tools and ceremonial ornaments (Redfield and Villa Rojas, 1962; Villa Rojas, 1987). Woven animal figures, stories about wild animals in oral history (Burns, 1983) and bird and mammal images on recently deciphered glyphs
(Schele and Freidel, 1992) also point to the role of wild animals in Maya art and mythology. The Maya's use of wild animals can be traced back to at least $7000 \mathrm{BC}$ (Nesbitt, 1980). Recent evidence from south-eastern Mexico shows that, although wild animals may be diminishing in importance as a source of food, hunting continues to be important culturally to modern Maya Indians.

The object of this paper is to examine subsistence hunting by contemporary Maya Indians in the context of their daily and seasonal activities, especially gardening. Gardens have been planted for millennia and are important both because of the crops they produce and the game they attract (Jorgenson, 1993). But gardens are not the only sites where wildlife is taken. Based on observations in south-eastern Mexico, the Maya also capture wild animals in the forest while engaged in various types of subsistence and commercial activities. Several factors thus affect Maya subsistence hunting practices.

\section{Study area and methods}

The study took place at Ejido X-Hazil y Anexos, State of Quintana Roo, Mexico, during 1989-90 (total area $552.95 \mathrm{sq} \mathrm{km}$; Figure 1; Jorgenson, 1993). Ejidos are properties where 


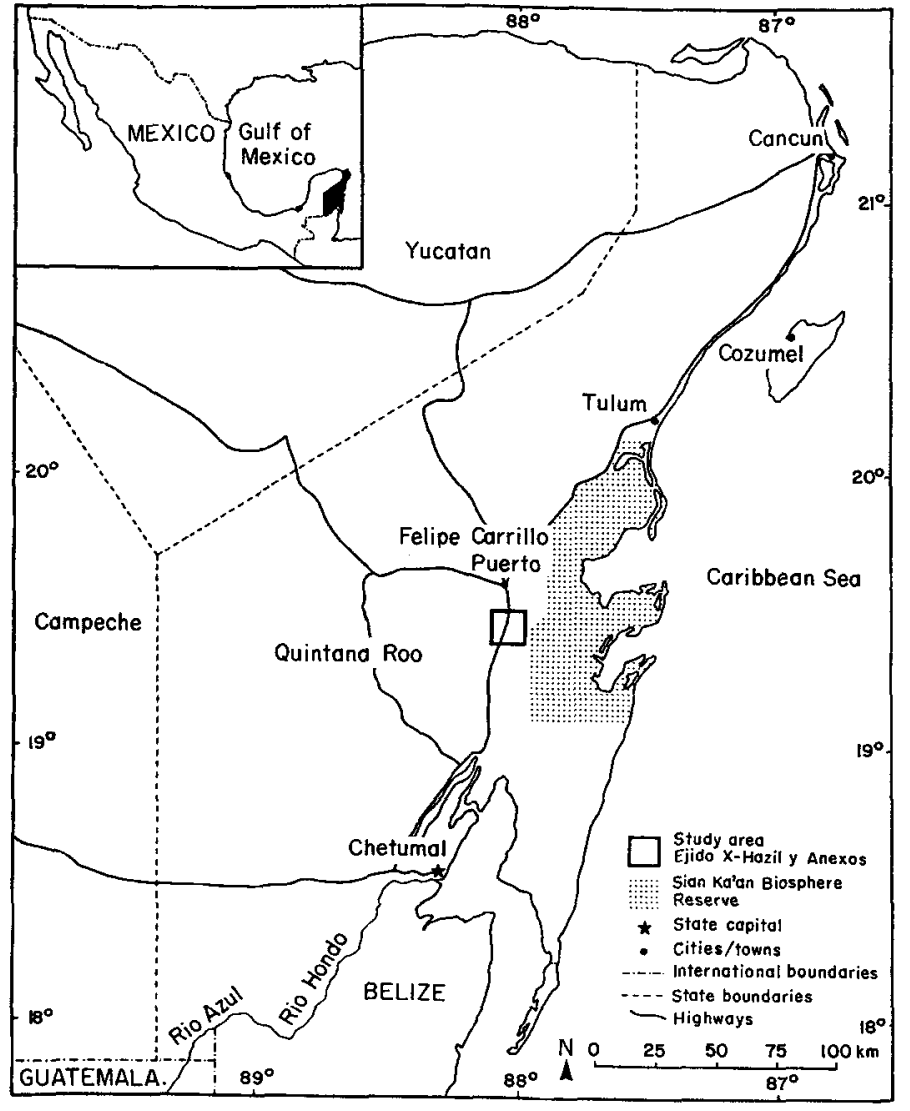

Figure 1. Location of Ejido XHazil y Anexos, State of Quintana Roo, Mexico. landless subsistence farmers have the legal right to use and profit from the natural resources of the area (Gordillo, 1988). In southeastern Mexico, ejidos were organized primarily to exploit lumber and non-timber forest products for the benefit of the resident communities.

Hunting data were obtained from co-operating hunters at the village of $\mathrm{X}$-Hazil Sur $\left(19^{\circ} 23^{\prime} 30^{\prime \prime} \mathrm{N}, 8^{\circ} 05^{\prime} 00^{\prime \prime} \mathrm{W}\right)$, the largest of three villages on the ejido (total population $=1680$ ). Most residents are Maya and were born in the village. A few mestizo (Indian/Spanish) families also lived on the ejido, having immigrated to the area from other parts of Mexico. Both Mayas and mestizo residents hunted wild animals and planted gardens.

The study area typically has one dry season (December-May) and one wet season (JuneNovember), with annual precipitation of about $1300 \mathrm{~mm}$. Gardening, hunting patterns, and other Maya subsistence and commercial activities are closely tied to the seasons. Based on forest surveys and interpretation of aerial photographs, 88.52 per cent of the ejido was categorized as late secondary forest (relatively undisturbed by human activity), 6.07 per cent as plots and gardens, 5.18 per cent as early secondary forest (recently fallowed areas), and 0.23 per cent as other types. According to villagers, the immediate area has been occupied by Maya Indians since about 1915 and their main subsistence activity is shifting cultivation, mainly for corn.

The contemporary Maya at Ejido X-Hazil y Anexos are highly acculturated, living in permanent settlements and raising domestic animals such as pigs, chickens and turkeys. They are neither peasants nor tribal people but villagers with systems of social relations based on loosely formed groups within the community. However, these groups are not equiva- 
lent to western social classes (A. F. Burns, per. comm.). Thus, comparisons with other Neotropical subsistence hunters, including peasants and tribal people may not be directly comparable.

The data presented here were collected during 1989-90 in the context of larger studies of Maya subsistence hunting (Jorgenson, 1993) and chicle tapping (the collection of chicle latex from sapodilla trees to produce chewing gum) (Barrera de Jorgenson, 1993). Game was identified and measured according to standard research methods. Collaborators provided information about the wild animals they hunted and gardens they planted. Village

Table 1. Reported number of individuals and total weight of game birds and mammals taken by Maya hunters at X-Hazil Sur, Quintana Roo, Mexico, June 1989-October 1990 (Jorgenson, 1993)

\begin{tabular}{lrcc}
\hline Game species & $\begin{array}{l}\text { Total no. } \\
\text { individuals }\end{array}$ & $\begin{array}{l}\text { Total weight } \\
(\mathrm{kg})^{*}\end{array}$ \\
\hline Mammals & & & \\
Pocket gopher & 53 & $(51) t$ & 22.3 \\
Paca & 47 & & 274.8 \\
Agouti & 35 & & 96.8 \\
Coati & 167 & & 504.9 \\
White-lipped peccary & 3 & & 94.3 \\
Collared peccary & 40 & $(36)$ & 618.5 \\
Brocket deer & 16 & & 250.0 \\
White-tailed deer & 24 & $(22)$ & 709.0 \\
Total & 385 & $(377)$ & $2,570.6$ \\
\% of all game & 66 & & 95 \\
& & & \\
Birds & & & \\
Thicket tinamou & 13 & & 4.9 \\
Great curassow & 13 & & 40.1 \\
Plain chachalaca & 167 & & 64.9 \\
Ocellated turkey & 6 & & 19.7 \\
Total & 199 & & 129.5 \\
\% of all game & 34 & & 5 \\
Mammals and birds & 584 & $(576)$ & 2700.1 \\
\hline
\end{tabular}

* Total weight for each species was determined by summing the weights of individual prey items. The degree of precision varied between species because different scales with assorted capacities and graduations were used.

+ Values in parentheses indicate number of individuals weighed if weight not available for all individuals in taxa. officials provided information about logging, chicle tapping and railway-sleeper cutting.

\section{Results}

\section{Maya hunters}

In 1989 the population of X-Hazil Sur was 950 residents in about 200 households. A total of 86 hunters reported taking game (Jorgenson, in press). Male hunters ranged in age from 10 to 60 years old, but the average hunter was about 29 years old. They constituted about 18 per cent of the male population, but the number and proportion of hunters were decreasing. Many elderly men said that they had recently quit hunting because the work was now too hard and the wildlife too scarce. In addition many hunters reported that their teenaged sons were not learning how to hunt because they were attending high school or were working away from the village.

The number of game kills per hunter varied greatly. During the 17-month study period, an average of seven animals were killed per hunter. Thirty-five hunters each reported only one kill, while the hunter with the greatest number of kills reported taking 85 animals. Seven hunters each reported 27 or more kills and accounted for 54 per cent of the total number of game birds and mammals taken.

\section{Wild animals taken as game}

Maya hunters harvested four taxa of birds ( $n=$ 199 individuals) and eight taxa of mammals for food ( $n=385$, Table 1), but did not take amphibians, reptiles or insects. This suggests that Maya hunters could be selective and did not have to capture all potentially edible wild animals in order to survive.

Most of the game was consumed by the hunter and his immediate family, but small quantities of meat were also sold locally or shared with other villagers at community festivals or religious ceremonies. The most frequently harvested mammals were the coati Nasua nasua ( $n=167)$, pocket gopher Orthogeomys hispidus ( $n=53)$, and paca Agouti paca $(n=47)$. 


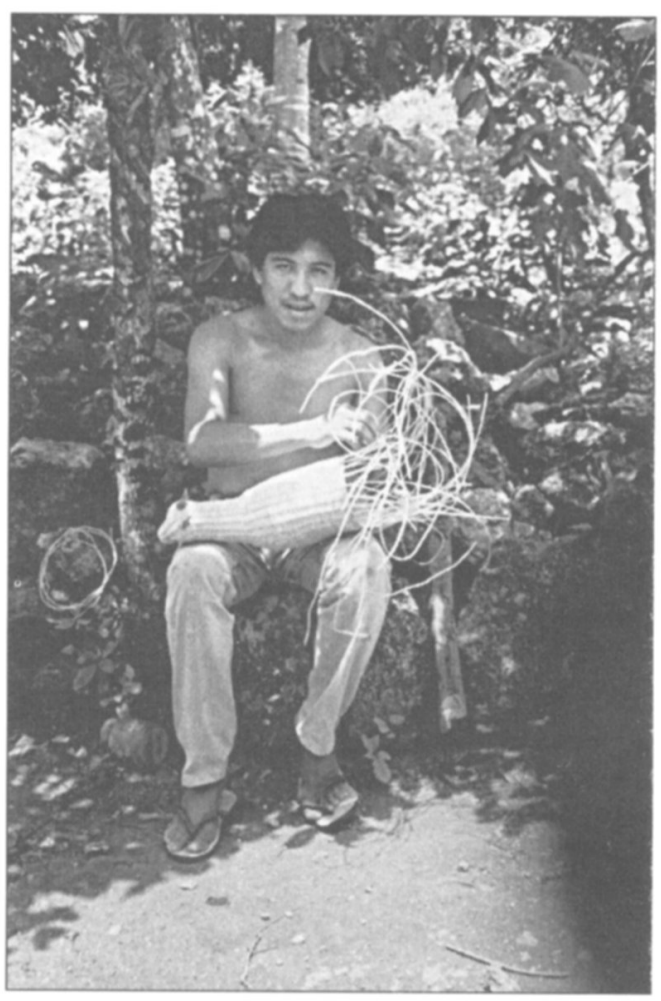

Maya craftspeople use brocket deer and white-tailed deer antlers in making animal figures sold to tourists in south-eastern Mexico.

The most frequently taken bird was the plain chachalaca Ortalis vetula $(n=167)$. The total weight of all game birds and mammals harvested during the 17 -month period was 2700 $\mathrm{kg}$, equivalent to about $2.0 \mathrm{~kg}$ per capita annually for each villager. By total weight harvested, the main mammals were white-tailed deer $(709.0 \mathrm{~kg} ; n=22)$, collared peccary $(618.5$ $\mathrm{kg}$; $n=36)$, and the coati $(504.9 \mathrm{~kg})$, while the main bird was the plain chachalaca $(64.9 \mathrm{~kg})$.

\section{Cultural context of Maya subsistence hunting}

Anecdotal information suggested that hunting or appearing to hunt was still culturally important. Several men were observed carrying guns to their gardens but they never reported a kill. When questioned about this, many said that they carried a gun mainly to keep up the appearance of being a hunter, and that they had not killed a wild animal for several years. Others said that their guns did not work or that they frequently did not have any ammunition. Despite these circumstances, many Maya men still felt a cultural need to carry a rifle or shotgun. These men were able to conceal the fact that they had not harvested any game because Maya hunters were not obliged to share their meat with family or friends or to announce publicly that they had made a kill.

Hunters at X-Hazil Sur no longer hunted several species of wild animals that had been hunted by their parents and grandparents. Perhaps the most surprising example of this change was the fact that they no longer hunted the armadillo Dasypus novemcinctus, although this species is still relatively common in south-eastern Mexico. Hunters also reported that they no longer hunted tapirs Tapirus bairdii, spider monkeys Ateles geoffroyi or howler monkeys Alouatta pigra. Hunters said that tapirs are difficult to locate because they occupy seasonally flooded lowlands $12-15 \mathrm{~km}$ from the village, along the eastern edge of the study area. In addition, tapir meat was reported to be not especially tasty, and a young tapir run down on the highway near the village in early 1989 was not salvaged. None of the hunters could remember having killed a tapir for at least 10 years prior to the study. Hunters reported that spider and howler monkeys were observed occasionally in the forest around the village but were becoming rare. Nobody expressed an interest in eating monkey meat, although many hunters said that their parents had eaten it in the past. Most hunters also said that now it was considered ethically incorrect to kill an adult female primate in order to capture and sell her dependent offspring.

\section{Maya gardens}

Most Maya living in rural areas still practise shifting cultivation, planting gardens in the forest in close proximity to the village, as they have done for thousands of years (Reina, 1967). Despite thousands of years of hunting pressure, however, Maya gardens and fallows throughout Central America continue to 
Maya hunter/gardener returning home on a bicycle after killing three white-lipped peccaries.

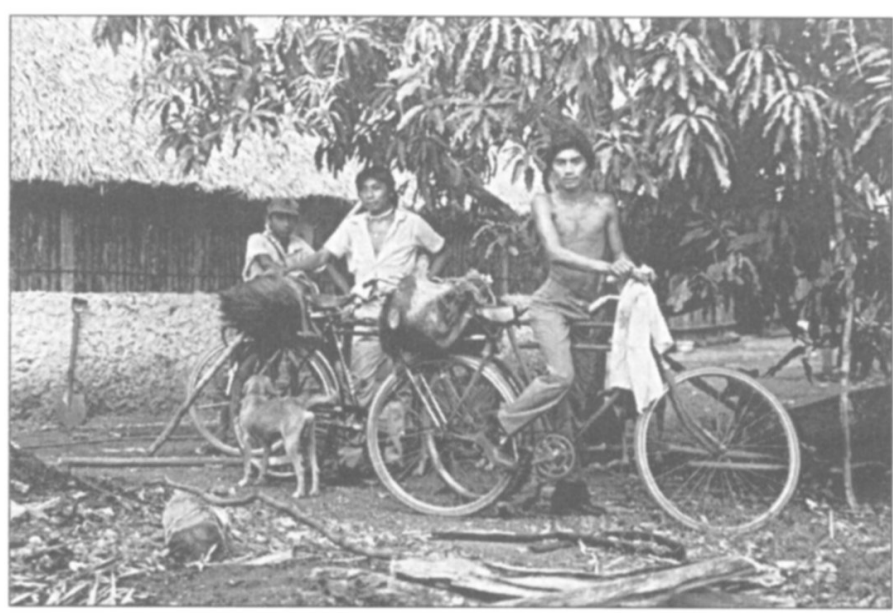

the main crop predators but the Maya did not eat them. Coatis were another main crop predator and were frequently taken while gardeners harvested corn during November-January. Gardens were used 1-3 years before being abandoned (Noguez-Galvez, 1991) but wild animals continued to use them, exploiting any crops that had not been harvested as well as early-successional plants that became established in the fallow period.

\section{Game harvest in plots and gardens}

Wild animals were not harvested equally throughout the different vegetation types of the study area. Gardens and fallow areas had a relatively high rate of game harvest (Jorgenson, 1993). Although the areas categorized as plots and gardens comprised only 6.07 per cent of the study area, the amount of game harvested there was much greater than 6.07 per cent of the total harvest for 8 of the 12 game taxa. Of 26 white-tailed deer killed, for example, 62.5 per cent were taken in plots and gardens. Pocket gophers, pacas, agoutis, coatis, collared peccaries, brocket deer and ocellated turkeys Agriocharis ocellata were also taken in plots and gardens at frequencies greater than expected. Great curassows Crax rubra and plain chachalacas were infrequently taken in these areas, while white-lipped peccaries Tayassu pecari and thicket tinamous Crypturellus cinnamomeus were not taken in plots and gardens. 


\section{Hunting with other activities}

Maya hunters at $\mathrm{X}$-Hazil Sur practised hunting as a single activity as well as in conjunction with other subsistence and commercial activities (Barrera de Jorgenson and Jorgenson, in press). About 59 per cent of successful outings occurred when hunting was the main activity (Table 2). Gardening and hunting were combined in 28 per cent of outings and accounted for 30 per cent (by numbers) of game birds and mammals killed. Hunters also killed game while logging, tapping sapodilla trees, cutting railway sleepers and conducting other activities in the forest.

\section{Discussion}

\section{Nutritional importance of game}

One of the main reasons people hunt is to obtain game for personal consumption (Lee and DeVore, 1968). Obtaining large amounts of game on a regular basis for subsistence, however, was no longer an obligatory activity for Maya hunters at X-Hazil Sur. At about $2.0 \mathrm{~kg}$ per capita annually (total body weight), the amount of game harvested during 1989-90 was insufficient to meet the nutritional needs of villagers. Given their reasonably good health and physical condition, it was apparent that they were meeting their protein needs through alternative sources.

Was the X-Hazil Sur pattern of using game as a nutritional supplement the normal practice among Maya hunters, or was it unusual due to some unknown factors? Contemporary studies of Maya villagers in three other areas have shown that when gardens, domestic animals and commercial activities were available, game was used to supplement other food sources. At the Maya village of Señor (total population about 2500; Ejido X-Maben; about $50 \mathrm{~km}$ north of X-Hazil Sur), about 43 per cent of the households included hunters, but almost all households raised domestic animals and 95 per cent planted gardens (Murphy, 1990). Nations and Nigh (1980) and March M. (1987) showed that, although Maya Indians in
Table 2. Number of successful hunting outings and number of game birds and mammals taken by Maya hunters, summarized by main activity of hunter during the outing

\begin{tabular}{lcc}
\hline & & $\begin{array}{l}\% \text { individuals } \\
\text { game species } \\
\text { taken } \\
(n=584)\end{array}$ \\
$\begin{array}{lcc}\text { Main activity } \\
(n=419)\end{array}$ & 56.8 \\
Hunting & 59.2 & 30.3 \\
Gardening & 28.2 & 6.5 \\
$\begin{array}{l}\text { Chicle tapping } \\
\text { Logging and railroad }\end{array}$ & 6.9 & 3.8 \\
tie cutting & 2.6 & 2.6 \\
Other & 3.1 & 100.0 \\
Total & 100.0 & \\
\hline
\end{tabular}

the Lacandon Forest, Chiapas State, southern Mexico, exploited at least 19 species of mammals, as well as fish and birds, hunting was not their main subsistence activity. The Lacandon Maya also harvested garden crops and raised cattle for sale.

In Guatemala, Maya hunters also used game to supplement food obtained from their gardens and through the sale of non-timber forest products, including chicle latex and xate Chamaedorea elegans fronds. At the village of Uaxactún, 639 inhabitants from about 150 families killed 572 game birds and mammals during 1992-93 (J. R. Morales Alvarez, in litt.). Despite cultural and environmental differences between Uaxactún and X-Hazil Sur, the numbers and kinds of game harvested were quite similar. Although not reported by Morales Alvarez, the total weight of these animals, using average body weights from the literature, would be about $6500 \mathrm{~kg}$, approximately $10 \mathrm{~kg}$ per capita annually. While the per capita average of $10 \mathrm{~kg}$ of game obtained at Uaxactún was substantially greater than the $2 \mathrm{~kg}$ obtained at X-Hazil Sur, this quantity of meat, if equally distributed throughout the village, would be nutritionally unimportant to the Maya. In fact, the game harvest was not equally distributed and a few hunters and their families enjoyed relatively large quantities of game. The fact that there were Maya hunters who regularly harvested small amount of game and continued to practise hunting under these circumstances, however, 
suggested that this activity was important for reasons other than the nutritional benefits.

\section{Cultural importance of subsistence hunting}

The Maya have harvested wild animals for thousands of years (Greenberg, 1992; Schele and Freidel, 1992). Despite this long tradition of hunting, the Maya have not developed a system whereby hunting is a major group activity within the village or where hunters accrue prestige or special privileges, as reported for many Amazonian tribal people (Chagnon, 1983; Stearman, 1989). Rather, it appears that an individual hunter's needs dictate when and how often he undertakes game outings (Redfield and Villa Rojas, 1962; Villa Rojas, 1987). Why, given the relatively small amount of game obtained versus the effort expended to harvest the animal, and the apparent lack of public recognition for this special skill, do Maya hunters persist in hunting? The results obtained at X-Hazil Sur suggested several possible reasons.

One of the main reasons for hunting was to kill potential crop predators. Many gardeners at X-Hazil Sur (Jorgenson, 1993), as well as at Señor (Murphy, 1990) and in the Lacandon Forest (Nations and Nigh, 1980; March M. 1987), reported that crop predation was a major problem. While some game species were more likely to be killed in late secondary forest or at great distances from gardens, 11 of the 12 game species taken at X-Hazil Sur used plots and gardens, at least part of the time. Maya hunters focused on those species and seldom hunted wild animals that did not use gardens (Jorgenson, 1993).

Killing crop predators also served an additional cultural function. Growing crops in a garden (milpa) is an important ethnic identifier that distinguishes Yucatec Maya from other people (Burns, 1983). Growing corn (santo gracia, sacred grace) is especially important and has religious connotations that extend beyond the simple tasks of planting, weeding and harvesting. After corn plants produce cobs, for example, Maya gardeners conduct a special ceremony of thanksgiving (primicia), which usually includes special foods prepared with game, especially white-tailed deer meat. In addition, the sack used to hold corn seeds during planting is used by local herbal doctors (curanderos) to cure life-threatening illnesses in Yucatec Mayan traditional medicine (Burns, 1983). By killing wild animals that could destroy a garden, Maya hunters protect the crops as well as reaffirm their ethnic identity.

\section{Maya cultural adaptation}

Contemporary Maya life in rural areas in south-eastern Mexico is a mixture of traditional activities, such as hunting and shifting cultivation and modern activities (Edwards, 1986). While traditional activities are usually for subsistence, modern activities, such as logging and chicle tapping, are generally for commercial purposes, providing the Maya with cash (Barrera de Jorgenson and Jorgenson, in press). At X-Hazil Sur, the Maya have used this money to obtain previously unavailable goods (for example, bicycles, televisions and motor vehicles) and services (for example, medical examinations by certified professionals and secondary education at schools in nearby cities). In the process many Maya cultural attitudes have changed, including some attitudes about subsistence hunting.

At X-Hazil Sur, it appears that two categories of Maya hunters have evolved in response to recent cultural changes in the area: traditional hunters and opportunistic hunters. Traditional hunters hunted frequently, ranged widely throughout the ejido, and took a relatively large number of wild animals (Jorgenson, 1993). Opportunistic hunters seldom hunted, visited few areas other than their gardens and took relatively few wild animals, often only one or two a year (Jorgenson, 1993). While socioeconomic data were not recorded in a systematic manner, traditional hunters often indicated a preference to hunt versus being active in village affairs or conducting commercial activities in the forest. They also frequently revealed a high level of self-esteem for their skills and knowledge. Only about five men could be categorized as traditional hunters; the rest were opportunistic. Many opportunistic hunters expressed regret at not 
killing more game, but cited the need to work full time at a wide variety of subsistence and commercial activities in order to feed and clothe their families. They said that it would be impossible to be successful at both hunting and commercial activities. As a compromise, many said that they hunted part time. While the amount of game that could be obtained this way was limited, opportunistic hunters expressed a degree of pride similar to that of traditional hunters at having killed a game bird or mammal. By combining hunting with other activities, it appears that contemporary Maya hunters are preserving a culturally important activity while simultaneously adapting to internal and external pressures to modernize their society.

\section{Acknowledgements}

Funding for this study was provided by World Wildlife Fund-US, World Nature Association, Roger and Bernita Jorgenson, Centro de Investigaciones de Quintana Roo (Mexican host agency), and Program for Studies in Tropical Conservation/Tropical Conservation and Development Program (University of Florida). The Secretaria de Desarrollo Urbano y Ecología kindly granted a research permit to work in Mexico. For permission to conduct research at Ejido X-Hazil y Anexos, I thank community officials and residents. I thank Kent $\mathrm{H}$. Redford and Richard E. Bodmer for their comments on an earlier version of the manuscript.

\section{References}

Ayres, J.M., de Magalhaes Lima, D., de Souza Martins, E. and Barreiros, J.L.K. 1991. On the track of the road: changes in subsistence hunting in a Brazilian Amazonian village. In Neotropical Wildlife Use and Conservation (eds J. G. Robinson and K. H. Redford), pp. 82-92. University of Chicago Press, Chicago.

Balée, W. 1985. Ka'apor ritual hunting. Human Ecology, 13 (4), 485-510.

Barrera de Jorgenson, A. 1993. Chicle extraction and conservation in Quintana Roo, Mexico. MA thesis, University of Florida, Gainesville..

Barrera de Jorgenson, A. and Jorgenson, J.P. In press. Use of forest resources and conservation in Quintana Roo, Mexico. Proceedings of the International Wildlife Management Congress, September 19-25 1993, San José, Costa Rica.

Bodmer, R.E., Fang, T.G. and Moya Ibañez, L. 1988.
Ungulate management and conservation in the Peruvian Amazon. Biological Conservation, 45, 303-310.

Burns, A.F. 1983. An Epoch of Miracles: Oral Literature of the Yucatec Maya. University of Texas Press, Austin.

Chagnon, N.A. 1983. Yanomamo: The Fierce People. 3rd edn. Holt, Rinehart and Winston, New York.

Dufour, D.L. 1990. Use of tropical rainforests by native Amazonians. BioScience, 40 (9), 652-659.

Edwards, C.R. 1986. The human impact on the forest in Quintana Roo, Mexico. Journal of Forestry, 30, 120-127.

Gordillo, G. 1988. Campesinos al asalto del cielo: de la expropiación estatal a la apropiación campesina. Siglo XXI Editores, México, DF.

Greenberg, L.S.Z. 1992. Garden hunting among the Yucatec Maya: a coevolutionary history of wild life and culture. Etnoecológica, 1 (1), 23-33.

Hamblin, N.L. 1984. Animal Use by the Cozumel Maya. University of Arizona Press, Tucson.

Jorgenson, J.P. 1993. Gardens, wildlife densities and subsistence hunting by Maya Indians in Quintana Roo, Mexico. PhD thesis, University of Florida, Gainesville.

Jorgenson, J.P. In press. Maya subsistence hunters in southeastern Mexico: a profile. In Proceedings of the International Wildlife Management Congress, September 19-25 1993, San José, Costa Rica.

Lee, R.B. and DeVore, I. (eds) 1968. Man the Hunter. Aldine Publishing Company, Chicago.

March, M., I.J. 1987. Los Lacandones de México y su relación con los mamíferos silvestres: un estudio etnozoológico. Biótica, 12 (1), 43-56.

McDonald, D.R. 1977. Food taboos: a primitive environmental protection agency (South America). Anthropos, 72, 734-748.

Murphy, J. 1990. Indigenous forest use and development in the 'Maya zone' of Quintana Roo, Mexico. MES thesis, York University, Ontario.

Nations, J.D. and Nigh, R.B. 1980. The evolutionary potential of Lacandon Maya sustained-yield tropical forest agriculture. Journal of Anthropological Research, 36 (1), 1-30.

Nesbitt, P.H. 1980. The Maya of Yucatán. In Yucatán: A World Apart (eds E. H. Mosely and E. D. Terry), pp. 41-59. University of Alabama Press, University of Alabama.

Noguez-Galvez, A.M. 1991. Changes in soil properties following shifting cultivation in Quintana Roo, Mexico. MA thesis, University of Florida, Gainesville.

Pohl, M.E.D. 1976. Ethnozoology of the Maya: an analysis of fauna from five sites in Peten, Guatemala. PhD thesis, Harvard University, Cambridge.

Redfield, R. and Villa Rojas, A. 1962. Chan Kom, a Maya Village. Carnegie Institution of Washington, 
Publication No. 448. (First published in 1934 by the University of Chicago Press.)

Redford, K.H. and Robinson, J.G. 1987. The game of choice: patterns of Indian and colonist hunting in the Neotropics. American Anthropologist, 89 (3), 650-667.

Reina, R.E. 1967. Milpas and milperos: implications for prehistoric times. American Anthropologist, 69, $1-20$.

Robinson, J.G. and Redford, K.H. (eds) 1991. Neotropical Wildlife Use and Conservation. University of Chicago Press, Chicago.

Ross, E.B. 1978. Food taboos, diet and hunting strategy: the adaptation to animals in Amazon cultural ecology. Current Anthropology, 19 (1), 1-16.

Schele, L. and Freidel, D. 1992. A Forest of Kings. Quill/William Morrow, New York.

Stearman, A.M. 1989. Yuquí foragers in the Bolivian Amazon: subsistence strategies, prestige and leadership in an acculturating society. Journal of Anthropological Research, 45, 219-244.
Thomsen, J.B. and Braütigam, A. 1991. Sustainable uses of Neotropical parrots. In Neotropical Wildlife Use and Conservation (eds J. G. Robinson and K. H. Redford), pp. 359-379. University of Chicago Press, Chicago.

Vickers, W.T. 1991. Hunting yields and game composition over ten years in an Amazon Indian territory. In Neotropical Wildlife Use and Conservation (eds J. G. Robinson and K. H. Redford), pp. 53-81. University of Chicago Press, Chicago.

Villa Rojas, A. 1987. Los elegidos de dios: etnografía de los mayas de Quintana Roo. Instituto Nacional Indigenista, México.

Yost, J.A. and Kelley, P.M. 1983. Shotguns, blowguns and spears: the analysis of technological efficiency. In Adaptive Responses of Native Amazonians (eds R. B. Hames and W. T. Vickers), pp. 189-224. Academic Press, New York.

Jeffrey P. Jorgenson, 2214 SW 70 Terrace, Gainesville, FL 32607-3793, USA. 